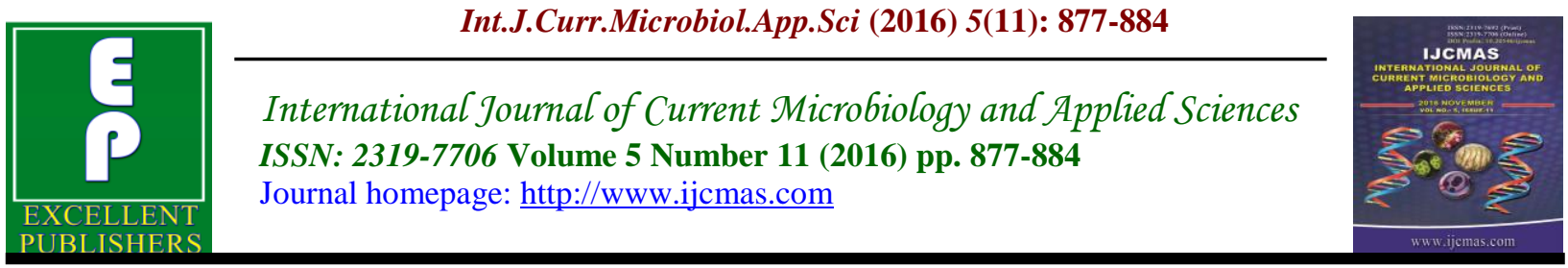

Original Research Article

http://dx.doi.org/10.20546/ijcmas.2016.511.100

\title{
Determination of PAH and BTEX in Water Samples of Adriatic Sea using GC/FID
}

\author{
Xhejni Borshi $^{1 *}$, Aurel Nuro ${ }^{2}$, Guido Macchiarelli ${ }^{1}$ and Maria Grazia Palmerini ${ }^{1}$ \\ ${ }^{1}$ Department of Life, Health and Environmental Sciences, University of L'Aquila, Italy \\ ${ }^{2}$ Chemistry Department, Faculty of Natural Sciences, University of Tirana, Albania
}

*Corresponding author

Keywords

Adriatic Sea, PAH, BTEX, Water samples, Gas chromatography.

\section{Article Info}

Accepted:

20 October 2016

Available Online:

10 November 2016
A B S T R A C T

The aim of this study was determination of polyaromatic hydrocarbons (PAHs) and Benzene, Toluene, o-, m-, p-Xylenes and Ethylbenzene (BTEX) concentrations in water samples from central Adriatic Sea, Durres, Albania. The stations were PortoRomano (PR), Port of Durres (PD) and Durres-Golem beach (DG). Water samples were taken in 18 stations (PR-6stations, PD-5 stations and DG-7 stations) in June 2016.The stations were selected in two important Albanian sea ports with higher shipping activities and in a coastal line for more than $15 \mathrm{~km}$. Determination of PAHs and BTEX were realized by gas chromatography with flame ionization detector. PAHs were extracted using liquid-liquid technique assisted by Dichloromethane as extracting solvent. After remove of water the samples were concentrated to $1 \mathrm{ml}$ and were injected in GC/FID.For extracting and injecting BTEX from water samples were used HS-SPME technique. Water samples, especially those taken from PR, showed higher concentrations of PAHs and BTEX compounds. This could be mostly due to ship-sourced oil, other than direct discharge of petroleum industry, naval and urban activities. This study highlighted the importance of a continuous monitoring of chemical pollution connected to human activities in the Adriatic Sea, in order to assess risks to the health or survival of wildlife species.

\section{Introduction}

Albania is a coastal country which has a 440 $\mathrm{km}$ long coastline. The Port of Durres is the main and the largest Port of the country and the Albania's Corridor VIII gateway, a European Network Corridor extremely important for manufacturing goods, cargo movement and passenger traffic between Albania and other countries. Albania currently has six commercial ports, the most important of which is the Port of Durres.
Despite recent investments made to improve the rehabilitation of the port's infrastructure, more investments are needed in order to achieve European standards.

Porto Romano is situated $7 \mathrm{~km}$ north of Durres city, facing the Adriatic Sea. During communism, the area was known for the Chemical Enterprise that produced pesticides for agriculture and sodium 
dichromate for leather tanning. After communism, in the 90', the Chemical Enterprise was abandoned and hundreds of tons of pesticides seriously contaminated water, soil and air in this area. PortoRomano considered one of the main hot-spot in Albania.

The Beach of Durres is the largest and most visited beach in Albania. It lines the seafront of the city of Durres and is about 10.5 kilometers $(6.5 \mathrm{mi})$ long. A number of notable Hotels overlook the beach. This destination is popular with people from Albania mainly from Middle and North Albania, Kosovo and the Macedonia.

The Albanian coastal zone is the area where, in the past few years, the social-economic development has been more intensive than in the rest of the country. Uncontrolled migration of the people to the coastal zone, thousands of illegal buildings were constructed without necessary infrastructure roads, water supply, sewerage, collection, transport and disposal of solid wastes, and constant increase of maritime transport produced a relevant impact to the marine environment. Ship pollution by illegal discharges of oil and oily mixtures into the sea has been the main cause of a recent marine and coastal pollution in the Albanian coastline (fig. 1), revealing the negligence of Institutions in preventing contaminations a highlighting the need for tighter regulations for ships entering the country's ports. Albania has also been slow in implementing regulations to ensure greater discipline regarding the waste management of ships anchored in the country's ports, and updating laws which intent to protect the marine environment of Albania from the pollution connected to human activity in the Adriatic Sea, decreasing the quality of water, damaging the coastal resource, endangering fauna and flora and threatening the human health.

\section{Materials and Methods}

\section{Sampling of water samples}

The samplings were realized in18 different stations in three main areas: Porto-Romano (6 stations), Port of Durres (5 stations) and Durres-Golem beach (7 stations). Water samples were taken in June 2016. 1.5 L of water were taken in Teflon bottles from each station. Water samples were tranported and conservated to the lab at $+4^{\circ} \mathrm{C}$ prior to analyzes.

\section{Preparation of water samples for PAH analyzes}

PAHs in water samples was extracted using liquid-liquid extraction (LLE) assisted with n-hexane solvent. $1 \mathrm{~L}$ of water and $30 \mathrm{ml} \mathrm{n}$ hexane as extract solvent was added in a separatory funel. After shaking, the organic phase was collected in a beker. Then was $\begin{array}{llllll}\text { added } & 5 & \mathrm{~g} & \mathrm{Na}_{2} \mathrm{SO}_{4} & \text { anhidrous for }\end{array}$ waterremoving. After concentration in $1 \mathrm{ml}$ n-hexane, samples were injected directly to GC/FID (Gustafson, 1997; Hartmann et al., 2004). PAH levels in water samples were expressed in $\mathrm{mg} / \mathrm{L}$.

\section{Preparation of water samples for BTEX analyzes}

Headspace solid phase micro extraction (HS-SPME) technique was used to trace BTEX in water samples. $5.0 \mathrm{~mL}$ of water sample was placed in a $10 \mathrm{~mL}$ headspace vial (5 replicate vials for each sample) to adsorb BTEX. The vials were placed in a heating block for $45 \mathrm{~min}$ at $50^{\circ} \mathrm{C}$. Extraction of volatile compounds was done using a $100 \mu \mathrm{m}$ Polydimethylsiloxane fibre in a SPME manual holder (Ho-Sang Shin, 2012). Direct injection in HS mode was performed in $280^{\circ} \mathrm{C}$ in a PTV injector. BTEX levels in water samples were expressed in $\mathrm{mg} / \mathrm{L}$. 


\section{Apparatus and chromatography}

Gas chromatographic analyses were realized with a Varian $450 \mathrm{GC}$ instrument equipped with a flame ionization detector and PTV detector. VF-1ms capillary column (30 m x $0.33 \mathrm{~mm} \times 0.25 \mu \mathrm{m}$ ) was used to isolate and determine BTEX and PAH compounds in separately injections. A temperature for FID was held at $280^{\circ} \mathrm{C}$. Nitrogen was used as carrier and make-up gas for both analyses. Hydrogen and air were flame detector gases with $30 \mathrm{ml} / \mathrm{min}$ and $300 \mathrm{ml} / \mathrm{min}$, respectively.

Injections of BTEX were done in injector PTV directly by using Head-Space mode $\left(280^{\circ} \mathrm{C}\right.$ for 15 seconds) of Polydimethyl Siloxane fiber. $1 \mu$ lextract in n-hexane (extracting solvent) were injected for PAH analyses. Quantification of BTEX and PAH was based on external standards. Three calibration points were selected with 10, 25 and $50 \mu \mathrm{g} / \mathrm{L}$ for BTEX. Three points of calibration were selected for PAH after diluted in n-hexane to concentrations 20,50 and $100 \mu \mathrm{g} / \mathrm{L}$ (Ho-Sang Shin, 2012; JCF et al., 2000).

\section{Results and Discussion}

Acenaphtalene, Fluorene, Phenanthrene, Antharcene, Pyrene, Benzo (a) Anthracene, Cryzene, Benzo (b) Fluoranthrene, Benzo (k) Fluoranthrene, Benzo (a) Pyrene, Dibenzo (a,h) Anthracene, Indeo (1,2,3,-cd) Pyrene and Benzo (g,h,i) Perilenewere 13 PAHs analyzed in all water samples of the Adriatic Sea. Total of PAH in water samples for each station was shown in Figure 3. The station PRW1showed the maximum level of total PAHs with $36.8 \mathrm{mg} / \mathrm{L}$, while minimum levels were found atPRW2, PRW3, PRW5, DGW3, DGW6 and DGW7, where PAHs were not detected or were lower than 0.1 $\mathrm{mg} / \mathrm{L}$. The mean concentration of PAHs was $7.7 \mathrm{mg} / \mathrm{Lin} \mathrm{PR}, 1.8 \mathrm{mg} / \mathrm{L}$ in PD and was 1.0 $\mathrm{mg} /$ Lin DG stations.
These data confirmed the high contamination of Porto-Romano, consequence of ship-sourced oil spill of the biggest naval activities of Albania. PAHs distribution in water samples (Fig.4) revealed the same contamination in PD and DG stations, because of the same origin of pollution. The PRW1 station showed a different distribution, evidence of some similarities with PRW4. Pollution of PR stations is connected to oil transfer by ships in oil deposits and vice-versa. It is not excluded that the high values found in PRW1 were connected to the specific momentum of sampling. The profile of PAH in Porto-Romanosamples (Fig.5) was: Crysene> Benzo (g,h,i) perileni> Benzo (a) antraceni> Benzo (a) pireni. The profile of PAHs in Port of Durres and Durres-Golem beach was: Acenaphtalene > Anthracene > Phenantrene> Pirene. Other PAHs were not detected or were less than the limit of detection $(0.05 \mathrm{mg} / \mathrm{L})$ of GC/FID technique. $\mathrm{PAH}$ levels and distribution is mainly associated with ship transports (especially oil ships), direct discharging of petroleum industry near this area, car servicing, urban waters, automobile transport and use of small boats. Levels were lower or comparable with other reported values in other areas and ports of Adriatic and Mediterranean Seas (Tuncel, 2011; Andral et al., 2004).

BTEX were found in around the $60 \%$ of analyzed samples. Total levels of BTEX for each sampling stations are reported in Figure 6. Stations PRW2, PRW6 and PRW3 had the maximum levels with13.4, 10.5 and $8.5 \mathrm{mg} / \mathrm{L}$, respectively.

Minimum values were observed for PRW5, PDW1 and all DG stations, where BTEX were not detected. The mean concentration of BTEX was $5.8 \mathrm{mg} / \mathrm{Lin} \mathrm{PR}, 0.2 \mathrm{mg} / \mathrm{L}$ in $\mathrm{PD}$ and was $0.01 \mathrm{mg} / \mathrm{Lin}$ DG. The same 
range of BTEX was observed for all the sampled areas. As for PAHs, PR stations showed the highest concentration of BTEX.

BTEX showed the same distribution in PD and DG stations because of the same origin of pollution (Fig. 7). Benzene was found at higher concentration at PRW2, PRW5 and PRW3 stations, compared with other compounds and other stations. Profile of BTEX in water samples of PR and PD stations (Fig.8) was: Benzene > Toluene > Xylenes > Ethylbenzene. DG stations showed an overlapping profile but with lower levels than in PR and PD stations.

Their presence in the PR and PD stations is connected to ship board oil pollution, ship transports, petroleum industry activities in these areas, automotive transport on roads near both ports, fishing boats activities.

Fig.1 Oil pollution connected to naval shipping (November 2015, Durres- Golem beach).

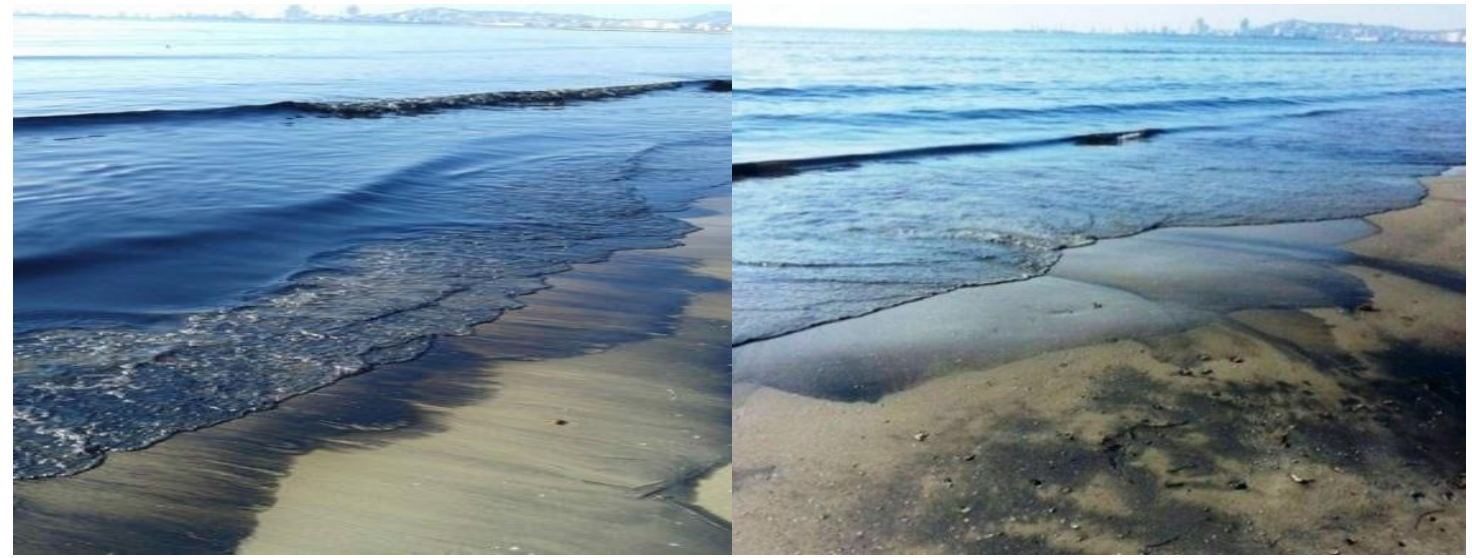

Fig.2 The sampling stations of sea water samples in Porto-Romano (PR), Port of Durres (PD) and Durres -Golem beach (DG)), June 2016

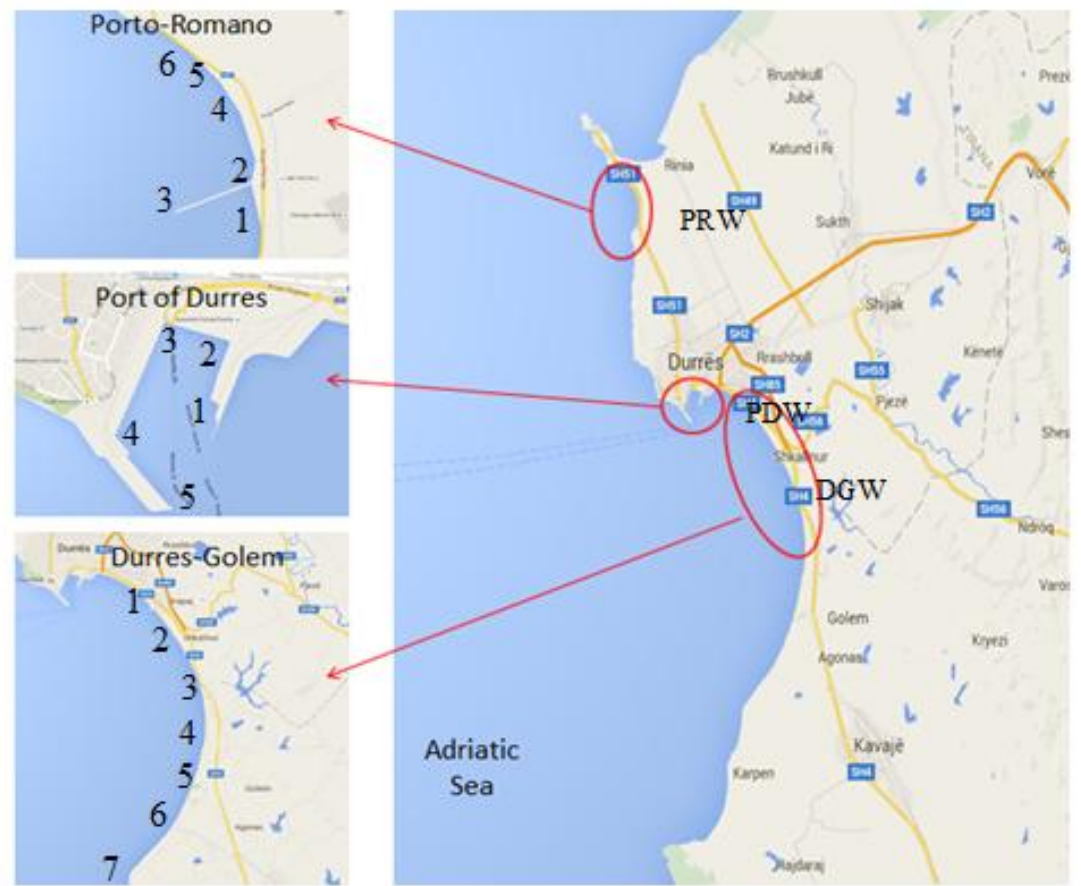


Fig.3 Total concentrations of PAH (mg/L) in sea water samples of Adriatic Sea, June2016

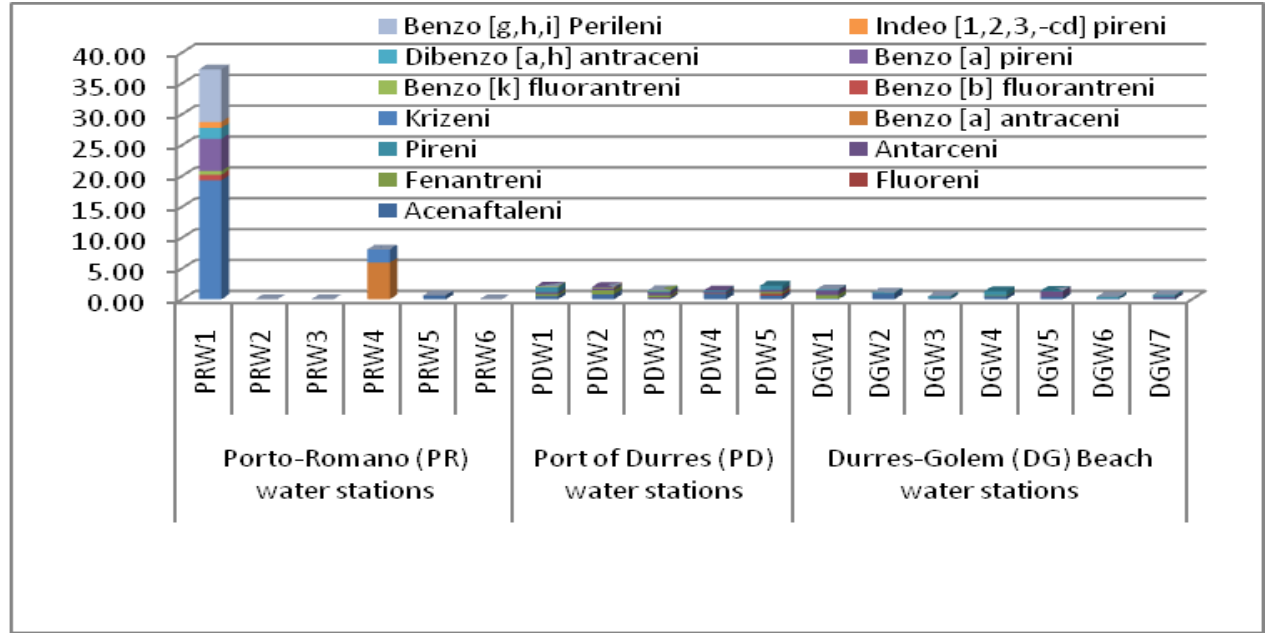

Fig.4 Distribution of PAH (mg/L) in sea water samples of Adriatic Sea, June 2016

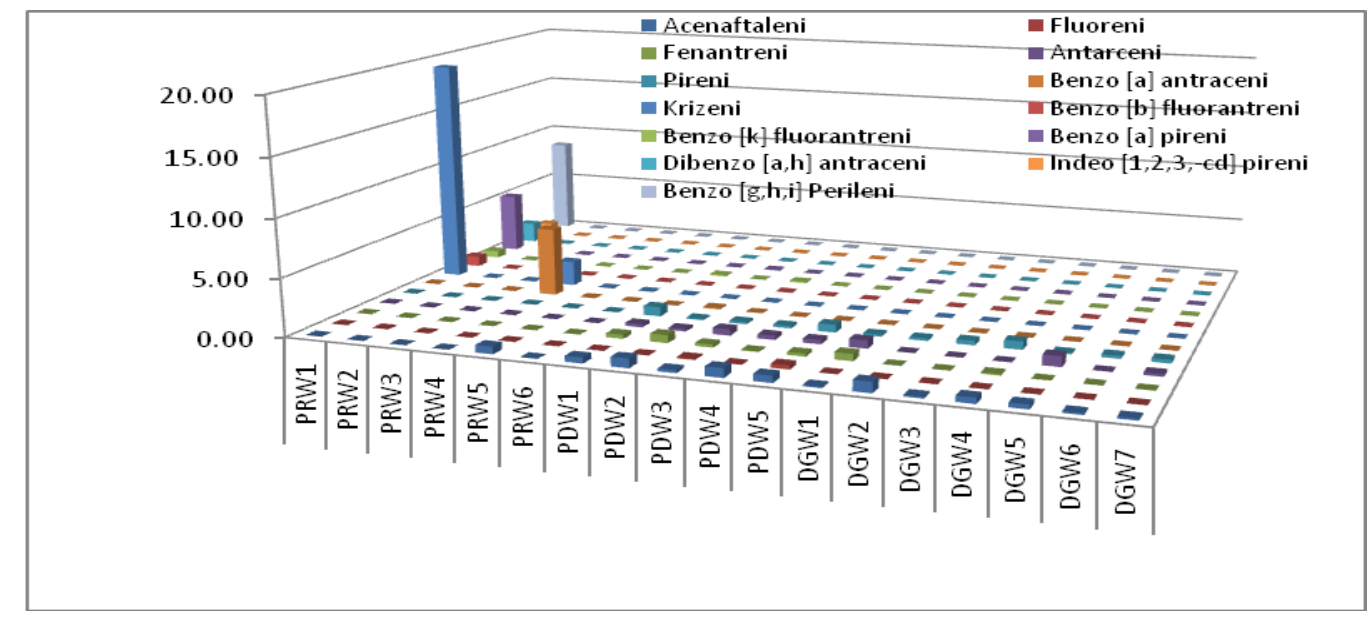

Fig.5 Profile of PAH (mg/L) in sea water samples of Adriatic Sea, June 2016

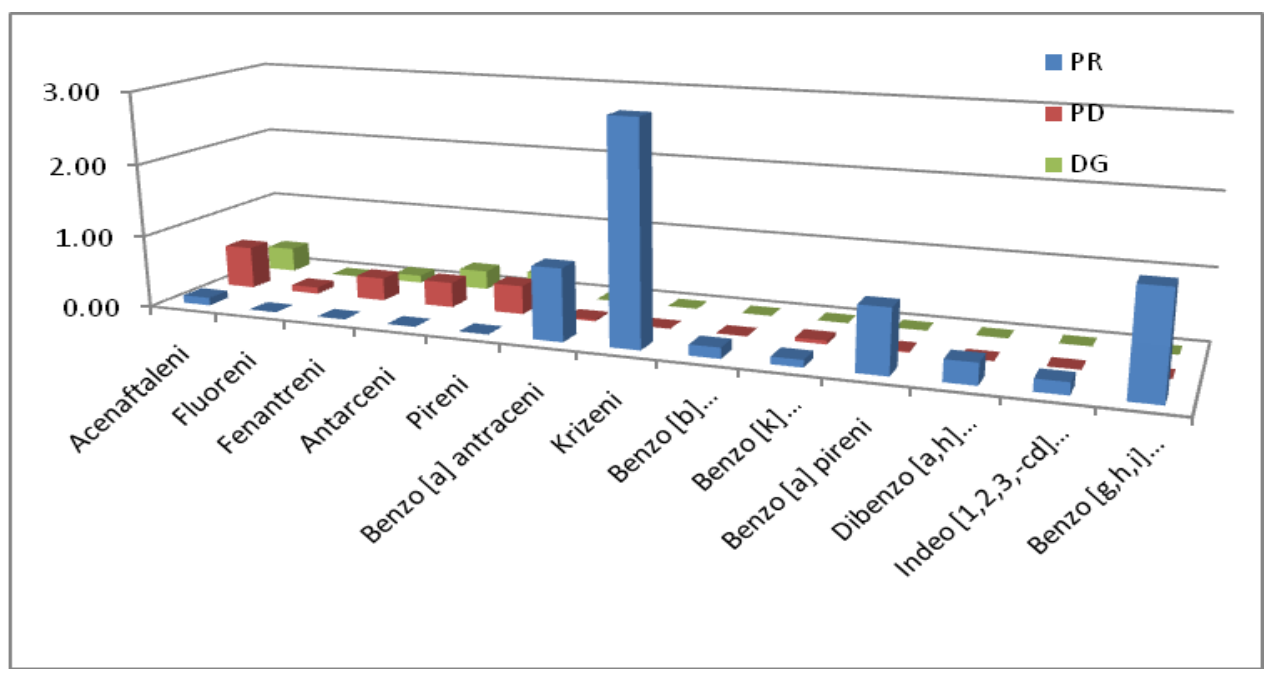


Fig.6 Total concentrations of BTEX (mg/L) in water samples of Adriatic Sea, June 2016

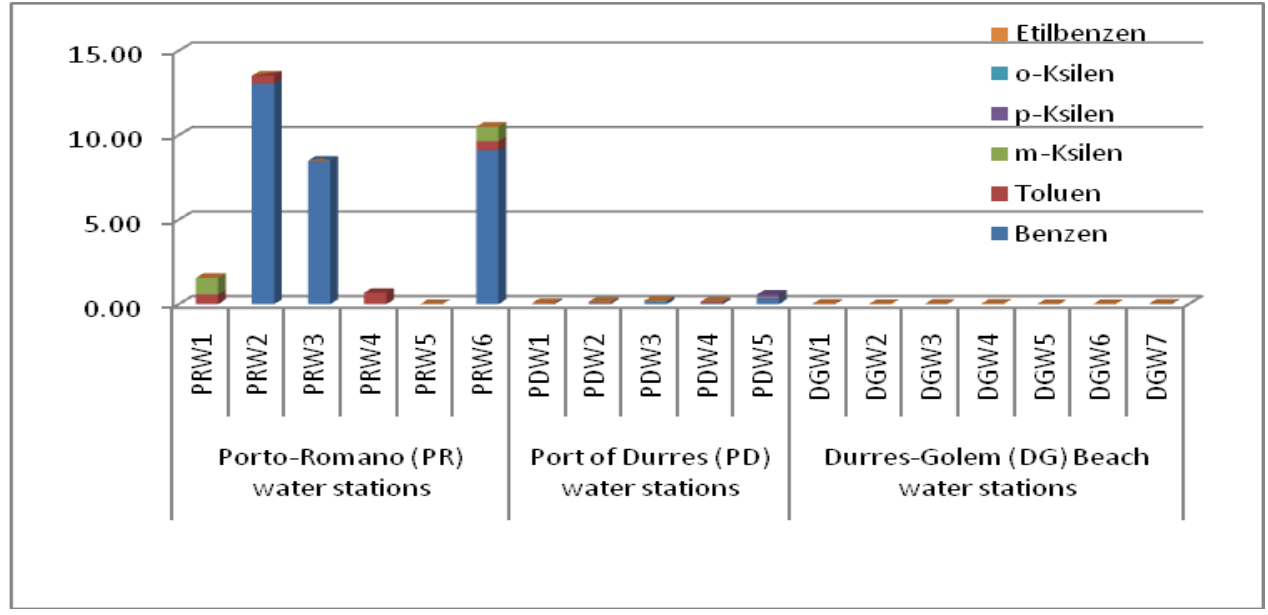

Fig.7 Distribution of BTEX (mg/L) in water samples of Adriatic Sea, June 2016

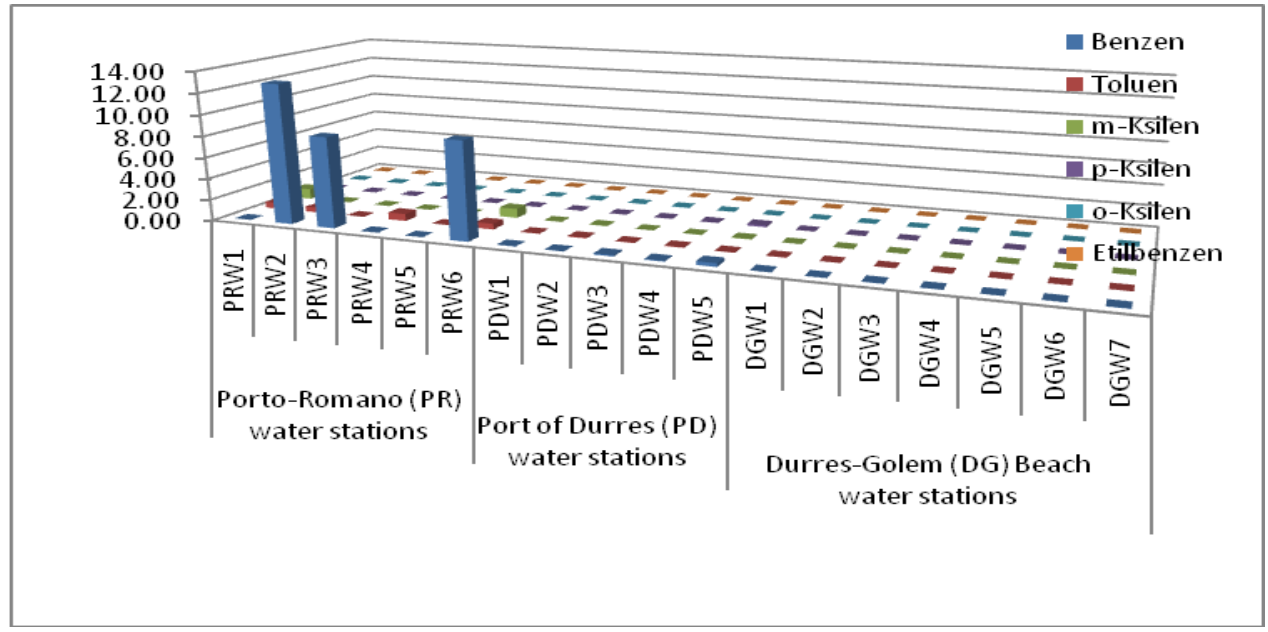

Fig.8 Profile of BTEX (mg/L) in water samples of Adriatic Sea, June 2016

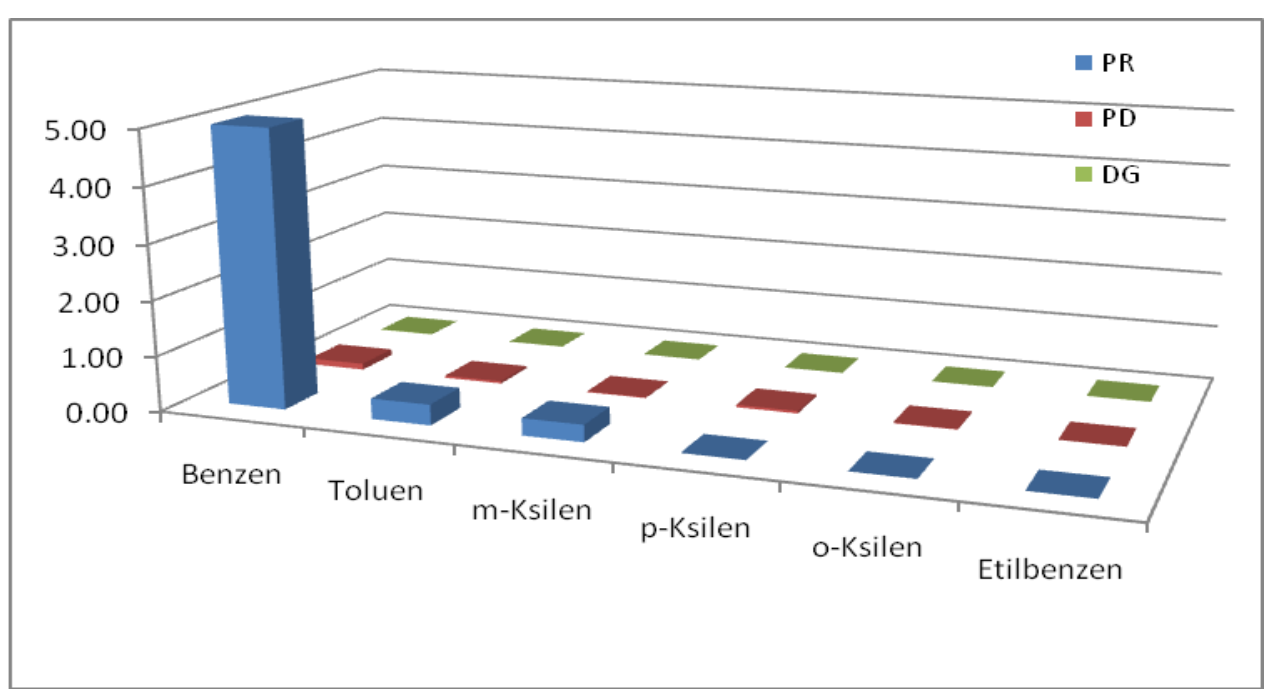


Levels found for PR stations were higher than those reported for marine waters in Adriatic and Mediterranean Seas (Quero et al., 2015; Bucchia et al., 2015). Values of BTEX in PD were around 40 times lower than those found in PR stations. Also in DG stations values were similar to the limit of detection of BTEX with GC/FID method. PD and DG stations showed lower values respect to those previously reported for marine waters in Adriatic and Mediterranean Seas.

In conclusion, Adriatic Sea water samples were taken in two important ports of Albania, characterized by the highest naval activities, Porto-Romano and Port of Durres, and in a coastal line (Durres-Golem) long more than $15 \mathrm{~km}$, appointed to have a large representation. The considerable presence of $\mathrm{PAH}$ and BTEX was due to direct discharging of petroleum industry near this area, car servicing, urban waters, automobile transport and use of small boats in marine waters. PAH and BTEX levels were lower or comparable with other reported values in other areas and ports of Adriatic and Mediterranean Seas. Different environmental conditions, as temperature, sunlight, sediment particle size and organic matter in sediment, can increase the persistence in the environment of $\mathrm{PAH}$, thus prolonging their toxic effects (Marini et al., 2013).

PAHs can affect human health through various way of exposure such as water and sea foods. Dietary intake is the predominant way of PAH exposure. Fish consumption plays an important role in the PAH intake in the food chain. Levels of PAHs in analyzed water sea stations (especially in PR and PG) show to be dangerous for the human health consumption of fishes that live in these areas (Wen-Jing et al., 2012). For some populations, in Albania, the consumption of fish represents an important component of the dietary habit. We suggest having consumption of fishes no more than two times in week for these populations (Boström et al., 2002). Benzo(a)pyrene $(\mathrm{B}(\mathrm{a}) \mathrm{P})$ is the main indicator of carcinogenic PAHs.

Authors suggest also a continuous monitoring of PAH, BTEX and other hydrocarbons and pollutants in the marine waters of the Albanian Adriatic Sea, associated with a more high sampling frequencies for GC/MS or GC/MS/MS analysis and to a long time span of observation, can give novel information on the pollution status of the Albanian coast of the Adriatic Sea. These data, associated to epidemiological studies, can be essential information on the human health in Albania.

\section{References}

Andral, B., J.Y. Stanisiere, D. Sauzade, E. Damier, H. Thebault, F. Galgani, P. Boissery, 2004. "Monitoring chemical contamination levels in the Mediterranean based on the use of mussel caging", Marine Pollution Bulletin, 49. 704 - 712.

Bajt, O. 2012. "Aliphatic and polycyclic aromatic hydrocarbons in sediments of the Slovenian coastal area (Gulf of Trieste, northernAdriatic)", Environ. Monitoring and Assessment, 184(12): 7439-52.

Boström, C.E., P. Gerde, A. Hanberg, B. Jernström, C. Johansson, T. Kyrklund, A. Rannug, M. Törnqvist, K. Victorin, R. Westerholm. 2002. "Cancer risk assessment, indicators, and guidelines for polycyclic aromatic hydrocarbons in the ambient air, Environ. Health Perspect, 451-88.

Bucchia, M., M. Camacho, M.R. Santos, L.D. Boada, P. Roncada, R. Mateo, M.E. Ortiz-Santaliestra, J. Rodríguez-Estival, M. Zumbado, J. Orós, L.A. HenríquezHernández, N. García-Álvarez ,O.P. 
Luzardo, 2015. "Plasma levels of pollutants are much higher in loggerhead turtle populations from the Adriatic Sea than in those from open waters (Eastern Atlantic Ocean)"Sci. Total Environ.,1523:161-9.

Gustafson, E., M. Dickhut 1997. Distribution of polycyclic aromatic hydrocarbons in southern Chesapeake Bay surface water: evaluation of three methods for determining freely dissolved water concentrations", Environ. Toxicol. Chem., 16: 452-461.

Hartmann, C., G. Quinn, W. Cairns, W. King. 2004. "The distribution and sources of polycyclic aromatic hydrocarbons in Narragansett Bay surface sediments", Marine Pollution Bulletin, 48, 351-358.

Ho-Sang Shin. 2012. "Determination of MTBE, TBA and BTEX in Soil by Headspace Gas Chromatography-Mass Spectrometry“, Bull. Korean Chem. Society, 33(5), 1693-1698.

Marini, M., E. Frapiccini, 2013. "Persistence of polycyclic aromatic hydrocarbons in sediments in the deeper area of the NorthernAdriaticSea(MediterraneanSea)“" , Chemosphere, 90(6):1839-46.

Menendéz, J.C.F., M.L.F. Sánchez, J.E.S. Uría, E.F. Martínez, A. Sanz-Medel, 2000. "Static headspace, solid-phase microextraction and headspace solidphase microextraction for BTEX determination in aqueous samples by gas chromatography", Analytica Chimica Acta, p. 415:9-20.
Perugini, $\quad$ M., P. Visciano, A. Giammarino, M., Manera, W., Di Nardo, M., Amorena. 2007. "Polycyclic aromatic hydrocarbons in marine organisms from the Adriatic Sea, Italy“, Chemosphere, 66(10): 1904-10.

Quero, G.M., D. Cassin, M. Botter, L. Perini, G.M. Luna. 2015. "Patterns of benthic bacterial diversity in coastal areas contaminated by heavy metals, polycyclic aromatic hydrocarbons (PAHs) and polychlorinated biphenyls (PCBs)“, Front Microbiol., 13(6): 1053.

Traven, L. 2013. "Sources, trends and ecotoxicological risks of PAHpollutionin surface sediments from the northernAdriaticSea(Croatia)“, Marine Pollu. Bull., 15; 77(1-2):445-50.

Tuncel, S.G., T. Topal, 2011. "Multifactorial Optimization Approach for Determination of Polycyclic Aromatic Hydrocarbons in Sea Sediments of Turkish Mediterranean Coast", American J. Anal. Chem., 2, 783794.

USEPA. 2009. "Measurement of purgeable organic compounds in water by capillary column gas chromatography/mass spectrometry", Method EPA, 524.3.

Wen-Jing Wu, Ning Qin, Wei He, Qi-Shuang $\mathrm{He}$, Hui-Ling Ouyang, and Fu-Liu $\mathrm{Xu}$, 2012. "Levels, Distribution, and Health Risks of Polycyclic Aromatic Hydrocarbons in Four Freshwater Edible Fish Species from the Beijing Market", Scientific World J.

\section{How to cite this article:}

Xhejni Borshi, Aurel Nuro, Guido Macchiarelli and Maria Grazia Palmerini. 2016. Determination of PAH and BTEX in Water Samples of Adriatic Sea using GC/FID. Int.J.Curr.Microbiol.App.Sci. 5(11): 877-884. doi: http://dx.doi.org/10.20546/ijcmas.2016.511.100 